\title{
Electrophoretic approach to the biochemical systematics of gammarids
}

\author{
H.-P. Bulnheim ${ }^{1} \&$ A. Scholl ${ }^{2}$ \\ ${ }^{1}$ Biologische Anstalt Helgoland (Zentrale); Notkestr. 31, D-2000 Hamburg 52, \\ Federal Republic of Germany \\ ${ }^{2}$ Zoologisches Institut der Universität; Baltzerstr. 8, CH-3012 Bern, Switzerland
}

\begin{abstract}
By utilizing the techniques for electrophoretic separation of proteins by vertical starch gels, the biochemical systematics of 10 Gammaridae species obtained from marine, brackish and freshwater habitats was studied. They included Chaetogammarus marinus, Gammarus zaddachi, $G$. salinus, G. oceanicus, G. tigrinus, G. chevreuxi, G. locusta, G. duebeni duebeni, G. d. celticus, G. pulex pulex, and $G$. fossarum. For comparison of electrophoretic mobilities selected enzymes (phosphoglucose isomerase, glutamate oxalacetate transaminase, arginine phosphokinase, hexokinase, leucine amino peptidase, mannose 6-phosphate isomerase) were assayed. They were used as diagnostic characters in terms of electrophoretic identities or diversities of most frequent alleles at polymorphic gene loci. These criteria could be applied to estimate intrageneric enzymic variation and degrees of genetic relatedness between the crustacean amphipod species under consideration, thereby complementing traditional morphological classification.
\end{abstract}

\section{INTRODUCTION}

The Gammaridae include a very large number of species inhabiting marine, brackish and fresh-waters, both epigean and hypogean. Their complex systematics has been subject of many studies and is still being treated at specific, generic and other levels of classification. In view of little morphological differentiation detected between several species and considerable variation of the characters used for diagnosis, certain members of the genus Gammarus proved to be a source of confusion for a long period of time. This is reflected, for example, by the publications dealing with the taxonomic analysis of the Gammarus zaddachi-complex (Sexton, 1912; Spooner, 1947; Segerstråle, 1947; Kinne, 1954) and the Gammarus locusta-group (Stock, 1967).

During recent years, several biochemical methods have been introduced as suitable tools for the study of taxonomic and evolutionary relationships between species, thereby complementing traditional morphological classification. Among the techniques applied, the separation of enzymes and other proteins by means of gel electrophoresis turned out to be of great relevance for distinguishing species and assessing their genetic relatedness. The measures used for this biochemical approach are based on relative electrophoretic mobilities of homologous enzyme proteins and on levels of allozymic variation.

The basic principle behind electrophoresis is the separation of proteins under the influence of an electric field. Proteins have an electric charge which depends on their 
amino-acid composition and the $\mathrm{pH}$ of the medium. The speed of migration during electrophoresis is determined by net charge and molecular size. When homologous proteins are compared, differences in electrophoretic mobilities indicate different amino-acid compositions, which, in turn, are coded by different genes. Thus electrophoretic mobility of proteins provides indirect information about DNA structure.

Since most amino-acid substitutions are not associated with charge changes, evidence given by electrophoresis as the major technique of biochemical systematics is limited to a certain degree. As Ferguson (1980, p. 42) expressed, the crux of the electrophoretic method is that "differences can be detected, but not similarities".

Advantages and limitations of electrophoretic data for systematics were also outlined by Avise (1974), who pointed out that much relevant information has accumulated as a byproduct of investigations on population genetics. To some extent this is also true for the present study. Based on previous work on the genetic divergence and geographic variation of the sibling species G. zaddachi Sexton and G. salinus Spooner (Bulnheim \& Scholl, 1980, 1981), it provides further results on the degree of interspecific differentiation of both amphipods. By including several other gammarids, the usefulness of enzyme electrophoresis for biochemical species diagnosis and for estimating taxonomic relationships is evaluated. The species additionally investigated comprise the euryhaline forms G. oceanicus Segerstråle, G. tigrinus Sexton, G. chevreuxi Sexton, G. duebeni duebeni Liljeborg, G. d. celticus Stock \& Pinkster, G. locusta (L.), Chaetogammarus marinus (Leach) $\cdot(=G$. marinus) as well as the freshwater inhabitants $G$. pulex pulex (L.) and $G$. fossarum Koch.

\section{MATERIALS}

The marine and brackish-water gammarids, widely distributed in the North East Atlantic, were obtained from various coastal or shallow water environments. In most cases, these were located in North Sea and Baltic Sea areas. The collecting sites of Gammarus zaddachi and $G$. salinus are listed in a recently published contribution (Bulnheim \& Scholl, 1981); this paper also refers to methods applied for sampling. The localities (given in brackets) for the other species were as follows: G. oceanicus (Fjord of Kiel, Lübeck Bay, Slite/Gotland), G. tigrinus (inner Fjord of Schlei, Fischerhütte/Kiel Canal, Emden harbour), G. chevreuxi (Dourduff estuary/Brittany), G. d. duebeni (inner Fjord of Schlei, Rantum basin/Sylt, Folhammar/Gotland), G. locusta (Wadden Sea of Sylt, Lübeck Bay), Chaetogammarus marinus (Helgoland, List/Sylt). Samples of $G$. locusta, $G$. oceanicus, G. salinus, $G$. zaddachi and $G$. duebeni were also taken at Vellerup/Isefjord (Denmark). The freshwater gammarids were collected at the following sites in the Federal Republic of Germany: G. p. pulex (Seeve/Jesteburg, brooks near Schätzendorf and Bockholmwik), G. fossarum (Waldprechtsbach near Malsch); $G$. $d$. celticus was obtained from Lesneven (Brittany, France).

\section{METHODS}

The enzyme patterns of at least 15-20 individuals from each of the species and subspecies studied were analysed. In several cases, however, the sample sizes were much larger. Before being processed for vertical starch gel electrophoresis (Buchler Instruments), the amphipods were kept for several days or weeks in aquaria. Homogeni- 
zation, centrifugation, preparation of starch gels (Connaught starch-hydrolysed), buffer systems and electrophoresis employed were as described previously (Bulnheim \& Scholl, 1981).

The following enzymes were assayed: arginine phosphokinase (APK), glutamate oxalacetate transaminase (GOT), hexokinase (HK), leucine amino peptidase (LAP), mannose-6-phosphate isomerase (M6PI) and phosphoglucose isomerase (PGI).

Staining techniques followed the procedures given by Bulnheim \& Scholl (1981) for APK, PGI and GOT; Brewer (1970, slightly modified) for HK; Selander et al. (1971) for LAP and Harris \& Hopkinson (1976) for M6PI. Tris-citrate gels and electrode buffer were used for GOT and PGI assays, Tris-borate EDTA gels and electrode buffer for the other enzymes. In some species ( $G$. pulex, $G$. fossarum) GOT and PGI could be also scored on Tris borate EDTA gels. Agar overlays prepared according to Scholl et al. (1978) were applied in combination with the specific enzyme stains to detect APK, M6PI and PGI.

Two GOT loci, presumably representing the soluble (GOT-1) and the mitochondrial (GOT-2) could be visualized; the former is the faster, the latter the slower migrating isozyme. In some cases, the assay for HK gave rise to two or three zones of activity. The data evaluation, however, was restricted to the fastest migrating zone, corresponding to HK-1.

The above six enzyme systems comprising seven loci could be successfully stained and consistently resolved in all species examined. Several other enzymes tested in the course of this electrophoretic survey (e.g. APH, ACPH, EST, MDH, ME, PGM) gave poorly defined bands or negative results in a few or single members of the Gammarus species group under study. These findings are in accordance with observations made by Gooch \& Hetrik (1979) who pointed out that amphipods do not electrophorese well, probably because of inhibitory enzymes elaborated by the digestive gland.

In addition to the enzyme assays performed, electrophocussing of proteins on prepared thin-layer polyacrylamide gel plates, containing Ampholine carrier ampholytes ( $\mathrm{pH} 3.5$ to 9.5 ) was applied. By use of the LKB Multiphor system, samples from the supernatants of homogenates were electrophoresed in a $\mathrm{pH}$ gradient; the gels were finally stained in a Coomassie Brilliant Blue solution.

These runs resulted in multiple species-specific banding patterns. In several species, however, resolution was poor. Therefore, this technique was excluded from further attempts to characterize the proteins from the various gammarids examined.

\section{RESULTS}

The electrophoretic approach, designed for analysing intrageneric variation, aimed at comparisons of the relative mobilities of the most frequent alleles. A common basis for this measure of genetic relatedness was provided by using Gammarus zaddachi as standard and performing parallel electrophoretic runs on gels. The allelic variants observed at the loci scored were designated according to anodal mobility of their protein products with reference to that measured in G. zaddachi. Therefore, the most frequent alleles at the given gene loci of this particular species were designed " 100 ". The electrophoretic mobilities of enzymatic allelic products relative to this tracking standard were computed by determination of the differences in migration distances (in millimeters) between the respective bands. Figure 1 shows a zymogram illustrating the species- 
Table 1. Reldtive electrophoretic mobilities of most frequent alleles in various gammarids. Less frequent alleles in brackets

\begin{tabular}{|c|c|c|c|c|c|c|c|}
\hline \multirow[b]{2}{*}{ Species } & \multicolumn{7}{|c|}{ Enzyme loci } \\
\hline & APK & PGI & M6PI & GOT-1 & GOT -2 & LAP & $\mathrm{HK}-1$ \\
\hline G. zaddachi & $\begin{array}{l}100 \\
(90)\end{array}$ & $\begin{array}{l}100 \\
(94)\end{array}$ & $\begin{array}{c}100 \\
(95,91)\end{array}$ & 100 & 100 & $\begin{array}{c}100 \\
(106)\end{array}$ & 100 \\
\hline G. salinus & 100 & $\begin{array}{l}100 \\
(94)\end{array}$ & $\begin{array}{l}100 \\
(95)\end{array}$ & $\begin{array}{l}100 \\
(96)\end{array}$ & 100 & 100 & 100 \\
\hline G. tigrinus & 100 & $\begin{array}{c}100 \\
(105)\end{array}$ & $\begin{array}{c}91 \\
(86)\end{array}$ & 100 & 100 & 100 & 100 \\
\hline G. occanicus & 100 & $\begin{array}{l}100 \\
(96)\end{array}$ & $\begin{array}{c}105 \\
(100)\end{array}$ & 100 & 100 & 102 & 102 \\
\hline G. chevreuxi & 95 & 96 & $\begin{array}{c}91 \\
(86)\end{array}$ & 100 & 94 & 99 & 102 \\
\hline C.marinus & 90 & 93 & 86 & 100 & 95 & 99 & 102 \\
\hline G. locusta & 100 & 94 & $\begin{array}{c}76 \\
(82)\end{array}$ & 96 & 102 & 99 & 102 \\
\hline G.d.duebeni & 89 & 96 & 110 & $\begin{array}{l}102 \\
(98)\end{array}$ & 93 & 99 & $\begin{array}{c}97 \\
(93)\end{array}$ \\
\hline G.d. celticus & 89 & 96 & 110 & $\begin{array}{l}102 \\
(98)\end{array}$ & 93 & 99 & $\begin{array}{c}97 \\
(93)\end{array}$ \\
\hline G. fossarum & 95 & $\begin{array}{c}106 \\
(112)\end{array}$ & $\begin{array}{c}92 \\
(100)\end{array}$ & 104 & 93 & 99 & 100 \\
\hline G.p.pulex & 95 & 107 & 112 & 102 & 93 & 99 & 102 \\
\hline
\end{tabular}

\section{Gammarus}

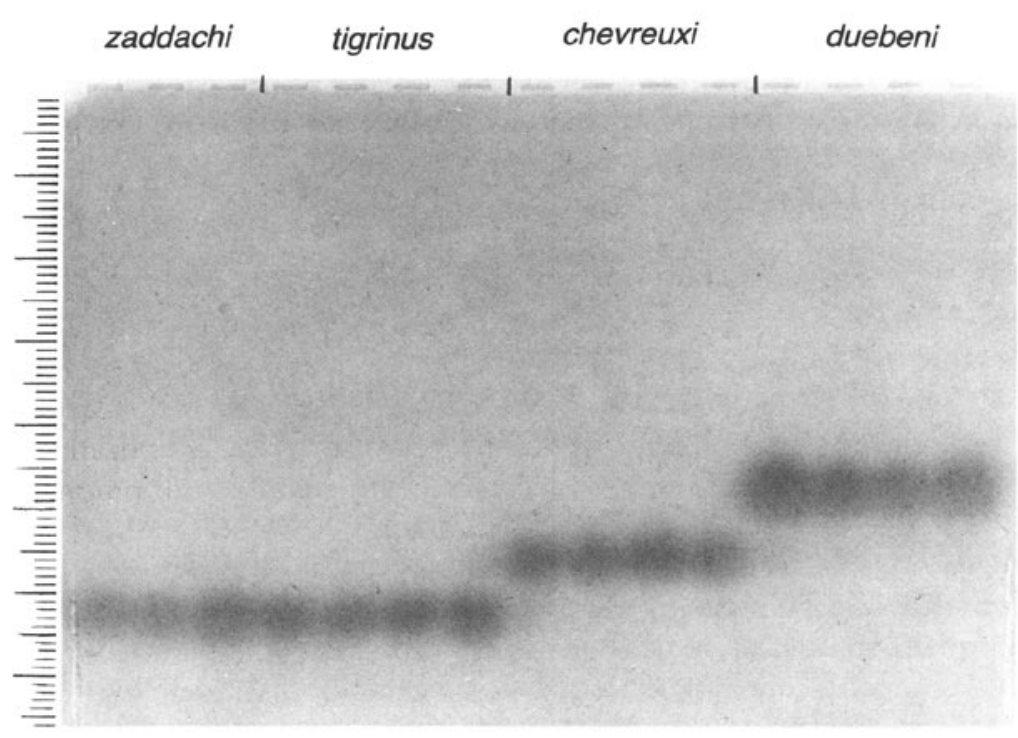

Fig. 1. Zymogram of APK showing electrophoretic mobilities for Gammarus zaddachi, G. tigrinus, $G$. chevreuxi, and $G$. d. duebeni. All enzyme phenotypes are monomorphic 


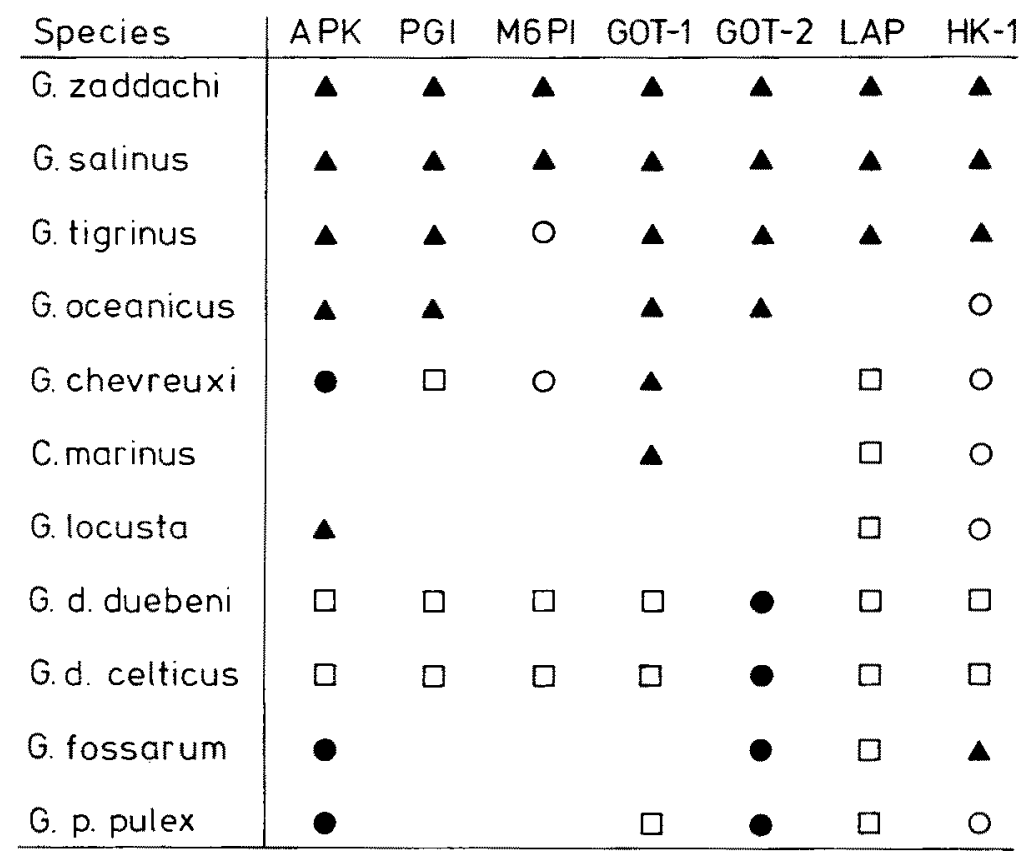

Fig. 2. Similarities and dissimilarities of the species investigated as revealed by electrophoretic evidence. Equal symbols designate identical electrophoretic mobilities. Absence of a symbol indicates distinction in this biochemical genetic character from all other species studied

specific banding pattern for APK. Table 1 gives the results of the comparison for all loci examined indicating most frequent and less frequent electromorphs. Differences in relative mobilities of most frequent alleles were not observed between samples of a given species obtained from different localities.

The distribution of allele frequencies at the PGI, GOT and APK loci has been extensively surveyed in a great number of G. zaddachi and G. salinus populations (Bulnheim \& Scholl, 1981). Since the samples examined and populations studied were relatively smaller in all other species considered here, the extent of the allelic diversity at polymorphic loci could not be sufficiently analysed. With regard to this limitation, the banding patterns observed permit only preliminary conclusions as yet on the genetic variation at the loci scored in most of the gammarids considered.

Many of the species examined exhibit genetic polymorphism at the PGI and M6PI loci. PGI was found to be highly polymorphic in G. zaddachi, G. salinus, G. oceanicus, $G$. tigrinus and $G$. fossarum. The other enzyme loci were shown to be monomorphic except for the few species listed in Table 1. M6PI polymorphism was observed in most of the species concerned except for the G. duebeni, G. pulex and C. marinus samples studied. In several $G$. zaddachi populations $\mathrm{M} \mathrm{PI}^{95}$ or $\mathrm{M}^{2} \mathrm{PI}^{91}$ were recognized as the dominant alleles.

Heterozygotes at the PGI and GOT loci could be visualized as three-banded phenotypes, as would be expected for a dimeric structure of the enzyme. The phenotypic pattern of the other enzymes studied exhibits two bands in heterozygotes, indicating a monomeric enzyme structure. 
The order of the amphipods listed in Table 1 reflects their increasing genetic distance to $G$. zaddachi, which was used as reference species here. Complementary to Table 1, as evidenced by the relative electrophoretic mobilities, similarities and dissimilarities between the gammarids under consideration are illustrated in Figure 2 . In this diagram, equal symbols are used to designate identical electrophoretic mobilities. The absence of a symbol for a given locus indicates a distinction in this particular character from all other species examined.

The close genetic relationship existing between $G$. zaddachi and $G$. salinus is clearly expressed by these comparisons. In all cases both forms share identical electrophoretic mobilities. However, they are distinct with respect to the polymorphisms observed at the APK, MGPI and LAP loci (G. zaddachi) and the GOT-1 locus (G. salinus). Also, G. oceanicus and, in particular, $G$. tigrinus have several of these electrophoretic characters in common with the siblings $G$. zaddachi and $G$. salinus, whereas $G$. chevreuxi and especially $G$. locusta as well as $C$. marinus differ much more from the above and the following species.

It is interesting to note that both $G$. pulex and $G$. fossarum, exhibiting a pronounced morphological similarity, have less electrophoretic characters in common than the species pair $G$. zaddachi and $G$. salinus. They differ in relative mobilities at four of the seven loci scored.

Between both $G$. $d$. duebeni and $G$. $d$. celticus enzyme electrophoresis did not reveal any differences in relative mobilities nor the presence of less frequent alleles at the polymorphic GOT-1 and HK-1 loci. This reflects a very close genetic relatedness.

Thus, except for these two forms, specific enzyme patterns could be observed which are species diagnostic for all other gammarids.

\section{DISCUSSION}

Taxonomists concerned with amphipods have made use, above all, of the morphological method of classification, which permits species and other taxa to be categorized according to the degree of structural similarities and dissimilarities. In addition to the morphological principle commonly used for species distinctions and phylogenetic reconstructions, Golikov \& Tzvetkova (1972) emphasized the application of palecological and biogeographical analysis. In several cases, further indications for taxonomic diagnosis were derived from ecological and physiological data as well as from results of crossbreeding experiments. The use of biochemical methods, also applied to taxonomic purposes in gammarids, was thus far restricted to chromatographic analysis of amino acid compositions (Roux, 1967a) and electrophoretic separation of non-specific esterases (Nyman \& Westin, 1969).

Although considerable progress has been made in clarifying the systematics of the Amphipoda in the course of the last decades, Karaman \& Pinkster (1977) pointed out that the genus Gammarus is not satisfactorily delimited and the taxonomy of the various species attributed to this genus, particularly of the freshwater forms, is not yet settled. Owing to considerable variability and convergent development of certain morphological characters, many taxonomic problems at the generic, species and subspecies level have remained a matter of debate. For a long period of time freshwater and marine forms were considered members of the same genus Gammarus. Though this opinion is still accepted 
by many authors, attempts have been made to subdivide the genus with reference to the aquatic environment inhabited. For the freshwater members, therefore, Karaman (1931) established the new genus Rivulogammarus and for mixohaline species Sket (1971) introduced the generic name Lagunogammarus. Additional new generic names were proposed for marine and brackish-water representatives of the genus Gammarus by Golikov \& Tzvetkova (1972). Similarly, Bousfield (1977) introduced a multitude of generic groups and reclassified the more than 1200 species of Gammaridae (sensu lato) which are presently known. For good reasons, Lincoln $(1979$, p. 238) concluded... "obviously there will be a great deal of discussion about these systematic manoevres in future years before there is any measure of agreement".

In an attempt to trace the trends of evolution in the genus Gammarus from cold and temperate waters of the northern hemisphere, Golikov \& Tzvetkova (1972) suggested that this taxon evolved in the basin of the Atlantic Ocean, the Tethys Sea, during the Paleogene period. With regard to species formation they came to the following conclusions: Boreal conditions in the Atlantic Ocean resulted in the formation of an independent subgenus Lagunogammarus. Its first representatives evolved during the second part of the Pliocene from the most ancient of the present-living forms, i.e. G. locusta. Among the presently existing species group $G$. wilkitzkii, G. kamtschaticus, G. setosus, $G$. oceanicus, G. zaddachi and G. salinus, the latter form may have originated first. $G$. zaddachi which has spread somewhat wider in the northwest Atlantic region than the more thermophilic G. salinus, presumably evolved later from this species or a common ancestor. In the late Pliocene, under sharply changing hydrological conditions, $G$. oceanicus may have evolved. Approximately at the same time the boreal brackish-water species $G$. duebeni may have originated. The evolution of the genus Chaetogammarus*, influenced by a similarly changing environment, appears to be analogous to that of the genus Gammarus.

In principle, the biochemical genetic information obtained from this study is in agreement with the above-reported conclusions on these groups of gammarids. Chaetogammarus marinus, G. locusta, G. duebeni, G. zaddachi (including G. salinus, $G$. tigrinus and $G$. oceanicus) and G. pulex (including G. fossarum) are different in several electrophoretic characters, indicating considerable genetic distances from each other and thus an evolutionary divergence during early periods of geological time.

In the following, the closely related species groups examined in this study will be considered in more detail. As previously mentioned, the $G$. zaddachi complex was insufficiently defined for several decades. Kinne (1954) divided it into three distinct species. Before this, some confusion existed about their taxonomic status which received subspecific rank by Spooner (1947) and Segerstråle (1947). Substantial electrophoretic evidence has been provided for close relationships between $G$. zaddachi and $G$. salinus. Nevertheless, as shown by the diverse allelic compositions documented in various populations of both amphipods from a large distribution area, their species character could be fully established (Bulnheim \& Scholl, 1981). G. oceanicus, however, appears to have distinct characteristics setting it apart from these siblings. This differentiation is also reflected by its geographic distribution and ecological requirements. G. oceanicus is

* The genera Chaetogammarus, Marinogammarus and Pectenogammarus have been synonymized with the genus Echinogammarus by Karaman (1975). 
a subarctic species exhibiting an amphiatlantic distribution. It occurs under brackish as well as full marine conditions, whereas $G$, zaddachi and $G$. salinus reveal an east Atlantic, boreal distribution. Both live in brackish environments; in areas exhibiting salinity gradients, the former prefers oligohaline, the latter mesohaline waters. These three species may coexist locally in the Baltic Sea and are often associated with $G$. locusta.

In contrast to the lusitanian species $G$. chevreuxi, a relatively high degree of relatedness of $G$. tigrinus to the $G$. zaddachi group is indicated. G. tigrinus, introduced from North America, is an immigrant to the British Isles and the European continent where it has spread rapidly during recent years (cf. Bulnheim, 1980).

G. duebeni is widely distributed in brackish coastal waters of varying salinities. In Ireland, parts of western Britain and Brittany (France) freshwater populations are known which are morphologically and physiologically distinct from brackish populations. These differences pertain to the length/width ratio of the merus from the 5 th pereiopod (Pinkster et al., 1970) and capacity of sodium regulation (Sutcliffe \& Shaw, 1968). According to these findings and the results of interfertile hybridization experiments, Stock \& Pinkster (1970) elevated them to subspecific level for which the names $G$. $d$. duebeni and $G$. $d$. celticus were proposed. Also from parasitological studies on infections by microsporidians, differences of sex-determining influences on the host became evident between both subspecies (Bulnheim, 1978). However, the electrophoretic evidence obtained has not yet revealed dissimilarities between them in the relative mobilities of the enzyme proteins examined. In this context reference is made to an examination of their subspecific status by Sutcliffe (1972). He pointed out that the morphological difference observed between $G$. $d$. duebeni and $G$. d. celticus is not associated with habitat salinity or previously determined physiological characteristics; it may be an instance of clinal variation reinforced by geographical isolation.

In a report on the fauna in the Danish Isefjord, Rasmussen (1973) described a pronounced variability of several morphological characters in the amphipods $G$. oceanicus, G. salinus, G. zaddachi, G. locusta and G. duebeni; therefore, he expressed some doubts on the distinctiveness of these species. However, the above-presented results on biochemical species discrimination by means of enzyme electrophoresis, which included material from this particular locality, clearly contradict this suggestion.

G. p. pulex and G. fossarum represent another species pair whose taxonomic status was the subject of considerable confusion and misidentifications. The latter form was considered a subspecies of $G$. pulex by Schellenberg (1942) and other authors; furthermore it was described under incorrect names (see Pinkster, 1972). Interbreeding experiments performed by Goedmakers (1972) and Pinkster (1972) demonstrated their reproductive isolation and thus their taxonomic distinctiveness. Intermediate forms observed between $G$. pulex and $G$. fossarum turned out to be not hybrids but members of another species, G. wautieri, newly established by Roux (1967b). In a revision of the G. pulexgroup and related species, Karaman \& Pinkster (1977) pointed out that, comparable to other groups of gammarids, a variety of morphological characters proved to be stable, while others were shown to be extremely variable. G. pulex includes several geographically limited subspecies (Karaman \& Pinkster, 1977) among which G. p. pulex is widely distributed in Europe and some areas of Asia. It is a common inhabitant of middle and lower reaches of streams, whereas $G$. fossarum prefers their upper reaches. With 
reference to the taxonomic status of both freshwater gammarids, additional proof of their species character is presented at the enzyme level by this study.

In conclusion, the findings reported here demonstrate that electrophoretic criteria can be additionally used as diagnostic aids in the systematics of gammarids, particularly at the species level. These criteria are related to relative electrophoretic mobilities of the protein products from selected loci and, provided several populations of closely related species can be compared, to the distribution of allele frequencies at such loci which are species diagnostic.

In view of the relatively low number of loci sampled in this study, coefficients of genetic similarity and distance (cf. Nei, 1972) commonly used for interspecific comparisons have not been computed. Dendrograms, resulting from these data, have not been produced either. For this purpose, more information on protein relationships is required, this being necessary to assess trends in the evolutionary processes as revealed by electrophoretic and other evidence.

Acknowledgements. We are very much indebted to $\mathrm{M}$. Mühlenkamp and S. Bahns for careful assistance during this work. Thanks are also due to Drs W. Besch (Karlsruhe), J. Dieleman and S. Pinkster (Amsterdam) for help in collecting some samples.

\section{LITERATURE CITED}

Avise, J. C., 1974. Systematic value of electrophoretic data. - Syst. Zool. 23, 465-481.

Bousfield, E. L., 1977. A new look at the systematics of gammaroidean amphipods of the world. Crustaceana (Suppl.) 4, 282-316.

Brewer, G. J., 1970. An introduction to isozyme technique. - Academic Press, London, $186 \mathrm{pp}$.

Bulnheim, H.-P., 1978. Interaction between genetic, external and parasitic factors in sex determination of the crustacean amphipod Gammarus duebeni. - Helgoländer wiss. Meeresunters. 31, 1-33.

Bulnheim, H.-P., 1980. Zum Vorkommen von Gammarus tigrinus im Nord-Ostsee-Kanal. - Arch. FischWiss. $30,67-73$.

Bulnheim, H.-P. \& Scholl, A., 1980. Evidence of genetic divergence between two brackish-water gammaridean sibling species. - Mar. Ecol. Prog. Ser. 3, 163-165.

Bulnheim, H.-P. \& Scholl, A., 1981. Genetic variation between geographic populations of the amphipods Gammarus zaddachi and G. salinus. - Mar. Biol. 64, 105-115.

Ferguson, A., 1980. Biochemical systematics and evolution. - Blackie, Glasgow, $194 \mathrm{pp}$.

Goedmakers, A., 1972. Gammarus fossarum Koch, 1835: Redescription based on neotype material and notes on its local variation (Crustacea, Amphipoda). - Bijdr. Dierk. 42, 124-138.

Golikov, A. N. \& Tzvetkova, N. L., 1972. The ecological principle of evolutionary reconstruction as illustrated by marine animals, - Mar. Biol. 14, 1-9.

Gooch, J. L. \& Hetrick, S. W., 1979. The relation of genetic structure to environmental structure: Gammarus minus in a Karst area. - Evolution 33, 192-206.

Harris, H. \& Hopkinson, D. A., 1976. Handbook of enzyme electrophoresis in human genetics. North-Holland, Amsterdam.

Karaman, S., 1931. 4. Beitrag zur Kenntnis der Süßwasseramphipoden. - Bull. Soc. scient. Skopje 9. 93-107.

Karaman, G. S, 1975. 69. Contribution to the knowledge of the Amphipoda. Revision of the Echinogammarus genera-complex (Fam. Gammaridae). - Arh. biol. nauka, Beograd 27,69-93.

Karaman, G. S. \& Pinkster, S., 1977. Freshwater Gammarus species from Europe, North Africa and adjacent regions of Asia (Crustacea-Amphipoda). Part I. Gammarus pulex-group and related species. - Bijdr, Dierk. 47, 1-97.

Kinne, O., 1954. Die Gammarus-Arten der Kieler Bucht. - Zool. Jb. (Syst. Okol. Tiere) 82, 405-425. 
Lincoln, R. J., 1979. British marine Amphipoda: Gammaridae. - British Museum, London, 658 pp. Nyman, L. \& Westin, L., 1969. A contribution to the methods of classification for some Mysidae and Gammarus species in the Baltic. - Inst. Freshwat. Res. Drottningholm, Rep. No. 49, 157-163.

Nei, M., 1972. Genetic distance between populations. - Am. Nat. 106, 283-292.

Pinkster, S., 1972. On members of the Gammarus pulex-group (Crustacea-Amphipoda) from Western Europe. - Bijdr. Dierk, 42, 164-191.

Pinkster, S., Dennert, A. L., Stock, B. \& Stock, J. H, 1970. The problem of European freshwater populations of Gammarus duebeni Lilljeborg, 1852. - Bijdr. Dierk. 40, 116-147.

Rasmussen, E., 1973. Systematics and ecology of the Isefjord marine fauna (Denmark). - Ophelia 11, $1-507$.

Roux, A. L., 1967a. Contribution à l'étude systématique des Gammares de groupe pulex (Crustacés Amphipodes): Application des méthodes chromatographiques de dosage des acides amines à des fins taxonomiques. - Bull. biol. Fr. Belg. 101, 115-128.

Roux, A. L., 1967b. Les Gammares du groupe pulex (Crustacés Amphipodes). - Essai de systématique biologique. - Thèse Fac. Sci., Univ. Lyon, 172 pp.

Schellenberg, A., 1942. Flohkrebse oder Amphipoda. - Tierwelt Dtl. 40, 1-252.

Scholl, A., Corzilius, B. \& Villwock, W., 1978. Beitrag zur Verwandtschaftsanalyse altweltlicher Zahnkarpfen der Tribus Aphaniini (Pisces, Cyprinodontidae) mit Hilfe elektrophoretischer Untersuchungsmethoden, - Z. zool. Syst. Evolutionsforsch. 16, 116-132.

Segerstrale, S., 1947. New observations on the distribution and morphology of the amphipod, Gammarus zaddachi Sexton, with notes on related species. - J. mar, biol. Ass. U. K. 27, $219-244$.

Selander, R. K., Smith, M. H., Yang, S. Y., Johnson, W. E. \& Gentry J. B., 1971. IV. Biochemical polymorphism and systematics in the genus Peromyscus. I. Variation in the old field mouse. Stud. Genet. (VI. Univ. Texas Publ.) 6, 49-90.

Sexton, E. W., 1912. Some brackish-water Amphipoda from the mouths of the Weser and the Elbe, and from the Baltic. - Proc. zool. Soc. Lond. 1912, 656-665.

Sket, B., 1971. Zur Systematik und Phylogenie der Gammarini (Amphipoda). - Bull. Sci. Cons. Acads RSF Youg. (A) 16, 6.

Spooner, G. M., 1947. The distribution of Gammarus species in estuaries. Part I. - J. mar. biol. Ass. U. K. $27,1-52$.

Stock, J. H., 1967. A revision of the European species of the Gammarus locusta-group (Crustacea, Amphipoda). - Zool. Verh., Leiden 90, 3-56.

Stock, J. H. \& Pinkster, S., 1970. Irish and French fresh water populations of Gammarus duebeni subspecifically different from brackish water populations. - Nature, Lond. 228, 874-875.

Sutcliffe, D. W., 1972. An examination of subspecific differences in the merus of the fifth walking leg of the amphipod Gammarus duebeni Lilljeborg. - Freshwat. Biol. 2, 203-216.

Sutcliffe, D. W. \& Shaw, J., 1968. Sodium regulation in the amphipod Gammarus duebeni Lilljeborg from freshwater localities in Ireland. - J. exp. Biol. 48, 339-358. 